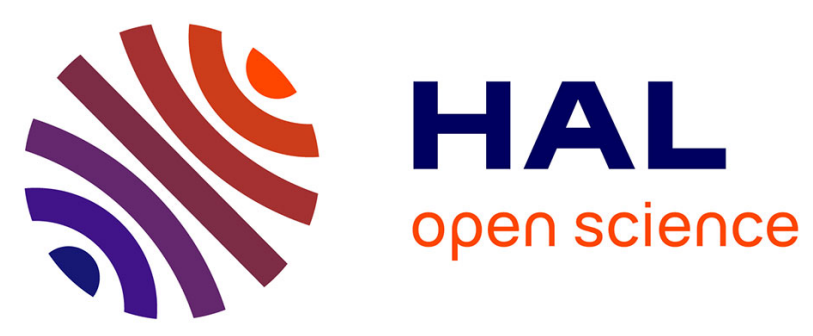

\title{
Treated wastewater Reuse in micro-irrigation: effect of shear stress on biofilm development kinetics and chemical precipitation
}

\author{
Nancy Rizk, Nassim Ait-Mouheb, Bruno Molle, Nicolas Roche
}

\section{To cite this version:}

Nancy Rizk, Nassim Ait-Mouheb, Bruno Molle, Nicolas Roche. Treated wastewater Reuse in microirrigation: effect of shear stress on biofilm development kinetics and chemical precipitation. Environmental Technology, 2019, 42 (2), pp.206-216. 10.1080/09593330.2019.1625956 . hal-02145454

\author{
HAL Id: hal-02145454 \\ https://hal.science/hal-02145454
}

Submitted on 18 Feb 2021

HAL is a multi-disciplinary open access archive for the deposit and dissemination of scientific research documents, whether they are published or not. The documents may come from teaching and research institutions in France or abroad, or from public or private research centers.
L'archive ouverte pluridisciplinaire HAL, est destinée au dépôt et à la diffusion de documents scientifiques de niveau recherche, publiés ou non, émanant des établissements d'enseignement et de recherche français ou étrangers, des laboratoires publics ou privés. 


\title{
Treated wastewater Reuse in micro-irrigation: effect of shear stress on
}

\section{biofilm development kinetics and chemical precipitation}

\author{
Nancy Rizk ${ }^{a b}$, Nassim Ait-Mouheb ${ }^{a}$, Bruno Molle $^{a}$ and Nicolas Roche ${ }^{b^{*}}$ \\ ${ }^{a}$ IRSTEA Montpellier, Université de Montpellier, 361 rue Jean-François Breton, 34090 \\ Montpellier, France \\ ${ }^{b}$ Aix Marseille Univ, CNRS, IRD, INRA, Coll France, CEREGE, BP 80, 13545 Aix-en- \\ Provence, France nicolas.roche@ univ-amu.fr
}

\begin{abstract}
Treated wastewater in micro-irrigation is a promising approach that could be used to decrease the pressure on water resources. However, the clogging of such systems due to biofilm development and chemical precipitation constitute a constraint with the use of treated wastewater (TWW) and lead to lowers irrigation system performance. The objective of this work is to study the development of biofilm and composition of fouling due to TWW under shear stresses of 0.7, 2.2 and 4.4 Pa detected along micro-irrigation systems. For this purpose, a Taylor-Couette reactor (TCR) was specifically calibrated for the cultivation of biofilm. The analysis of fouling composition samples (organic and inorganic) shows that biofilm tends to develop under the highest shear stress value (4.4 Pa). Precipitation of calcium carbonate in the form of calcite was observed in conjunction with biofilm growth using X-ray diffractometry (XRD) and thermogravimetric analysis (TGA). These results can be used to ascertain the origins of chemical and biological clogging of dripper and fouling of pipes related to reclaimed water- irrigation.
\end{abstract}

Keywords: Biofilm, chemical precipitation, micro-irrigation, shear stress, Taylor-Couette reactor, treated wastewater. 


\section{Introduction}

Reuse of treated wastewater for irrigation and especially in micro-irrigation, would appear to an efficient way to mitigate the problem of water resource rarefaction, especially in arid and semi-arid countries (Megersa and Abdullahi 2015). Micro-irrigation, also known as drip irrigation, is an irrigation technique characterized by low, frequent and localized water delivery to crops in the form of drops using drippers (Bounoua 2010). However, dripper clogging is a common problem in micro-irrigation (Liu and Huang 2009; Niu et al. 2012), and notably when treated wastewater is used (Dazhuang et al. 2009; Gamri et al. 2014). Clogging can be physical (caused by accumulated suspended solids), organic (linked to algae and biofilm growth) and / or chemical (due to precipitation of chemical elements) and can be observed simultaneously (Bucks et al. 1979). There are several factors that can influence lateral fouling and dripper clogging, hydrodynamic conditions, in particular, influences the composition, structure, morphology and the activity of the biofilm (Besemer et al. 2007; Araujo et al. 2016; Thomen et al. 2017). In order to understand how hydrodynamic conditions can influence biofilm development and dripper clogging, several experimental and numerical studies on drippers and pipes have been performed. Wei et al. (2006) and Al Muhammad (2016) used a method based of computational fluid dynamics (CFD) to calculate pressure distribution and flow velocity inside dripper channels. According to CFD simulations, changes in pressure gradients mainly occur at the angles formed by channel walls. Gamri et al. (2014) shows that the lowest velocity inside a dripper occurs in the central circle and at some angles of the dripper channels, which are the areas where biofilms principally develop. Velocity vector distribution confirms that these areas are characterized by swirls where water recirculates, thus facilitating biomass growth and causing detached biofilm fragments to deposit. In pipes, the liquid velocity at the solid-liquid interface is negligible resulting in a boundary layer characterized by high shear forces and velocity gradients (Landau and Lifchitz 
1989). With low flow velocities, the boundary layer becomes thicker and provides favorable conditions for the slow but constant adhesion of bacteria over time. However, higher flow velocities amplify the adhesion strength of biofilm (Chen et al. 2005), and this favors the transport of the substrate through the porous biofilm, which contributes to its development (Characklis et al. 1982; Wäsche et al. 2002). On the other hand excessively high speeds determine shear forces which induce a delay in the initiation phase (21 days for $1.2 \mathrm{~m} \mathrm{~s}^{-1}$ instead of 10 days for $0.8 \mathrm{~m} \mathrm{~s}^{-1}$ ) (Gamri 2014) and detachment of bacterial cells (Donlan 2002; Horn et al. 2003).

According to Li et al. (2012) the flow velocity inside pipes transporting reclaimed wastewater for micro-irrigation influences the growth and surface topography of biofilms. For the aforementioned work, polyethylene pipes with an outside diameter of $16 \mathrm{~mm}$ and inside diameter of $13.8 \mathrm{~mm}$ were used. Different flow velocities were studied from 0.06 , to $1.78 \mathrm{~m} \mathrm{~s}$ ${ }^{1}$ (916 < $\left.\operatorname{Re}<29340\right)$. The average biofilm thickness reached its maximum at velocity $0.45 \mathrm{~m}$ $\mathrm{s}^{-1}$ with a shear stress of $0.81 \mathrm{~Pa}$ under a turbulent regime $(\mathrm{Re}=7334)$. Other research studies have shown that very high velocities determine shear stress on the biofilm, which leads to the detachment of some or all of the biofilm (Characklis 1981; Melo and Vieira 1999; Horn et al. 2003; Derlon et al. 2008). Since the present study is on micro-irrigation, the conditions of shear stresses selected are those found in irrigation pipes and drippers. As the study of biofilm development inside drippers and pipes at defined shear stress is difficult, a Taylor-Couette reactor (TCR) is used as a powerful tool to study the effect of hydrodynamic condition on biofilm development. TCR is a rotating annular bioreactor (RAB) that provides a constant shear stress distribution and growth of biofilm in a turbulent flow environment (Characklis 1990; Gomes et al. 2014). Understanding and mastering TCR hydrodynamic conditions can facilitate the comprehension of biofilm initiation, development and detachment. Previous TCR studies using wastewater showed that biofilm presents three detachment zones related to 
the range of shear stress. Detachment is greater inside the first zone (for shear stress values below $0.3 \mathrm{~Pa}$ ) than at the second (for shear stress ranging from 0.3 to $2 \mathrm{~Pa}$ ), the third zone can resist shear stress magnitude up to $13 \mathrm{~Pa}$ (Derlon et al. 2007). Rochex et al. (2008) observed that an increase in shear stress from $0.055 \mathrm{~Pa}$ to $0.27 \mathrm{~Pa}$ in the same TCR: reduces the diversity of bacterial communities that colonize surfaces, slows down biofilm maturation, and tends to preserve a young biofilm.

The objective of this paper is to study the kinetic development of biofilm and associated inorganic precipitation inside a turbulent flow regime under different shear stress using a TCR when treated wastewater is used. The originality of this work lies in the rendering of microirrigation conditions inside the TCR using real effluent.

\section{Materials and methods}

\section{Biofilm development under different shear stresses}

Biofilm was cultivated in a co-axial Taylor-Couette reactor (TCR) under selected shear-stress conditions found in irrigation pipes and drippers. Co-axial TCR provide constant wall shear stress distribution on surfaces and are suitable for the cultivation of biofilm in turbulent flow environments (Krivilyov et al. 2006). The liquid phase occurs between two cylinders, and the biofilm grows on low density polyethylene (LDPE) plates fixed to the rotating inner cylinder. The inner cylinder of the TCR was encircled with five removable polyvinyl chloride (PVC) rings which are mounted with the LDPE plates (figure 1). PVC was chosen as it is a rigid and light support for better plate mounting and to minimize friction at the bottom of the reactor, which can cause water overheating. LDPE is the plastic material chosen because it is widely use in all micro-irrigation systems assembly. [Figure 1 near here]. 
The five plates are used for biofilm development monitoring over time. Each plate represents a definite age of biofilm. The total surface available for biofilm growth was $0.1216 \mathrm{~m}^{2}$ $\left(0.02432 \mathrm{~m}^{2}\right.$ for each plate: length $=0.605 \mathrm{~m}$ and width $\left.=0.04 \mathrm{~m}\right)$. Plates were fixed with six stainless screws at their ends and integrated in the cylinder. Thus liquid phase flow perturbations due to geometrical irregularities are minimized. The cylinders have a height of $0.2 \mathrm{~m}(\mathrm{~h})$. The rotating inner cylinder had a radius of $0.1065 \mathrm{~m}\left(\mathrm{R}_{1}\right)$. The fixed outer cylinder had a radius of $0.1195 \mathrm{~m}\left(\mathrm{R}_{2}\right)$. The hydrodynamic stress was governed by the size/width of the gap $\left(\mathrm{e}=\mathrm{R}_{2}-\mathrm{R}_{1}=0.013 \mathrm{~m}\right.$ ) between cylinders, and by the rotational speed of the inner cylinder $(\Omega)$.

\section{Hydrodynamic regime and shear stress}

In a TCR, the rotation speed of the inner cylinder and the radii of the two cylinders define the flow regime. The flow is characterized by a dimensionless number called the Reynolds number (Re) (Equation 1). The Reynolds number is the ratio of inertia forces to viscous forces. It is expressed in the case of a co-axial-reactor as follows:

$R e=\frac{\Omega R_{1}\left(R_{2}-R_{1}\right)}{v}$

Where $\Omega$ is the angular velocity of the inner cylinder $\left(\operatorname{rad~s}^{-1}\right)$ and $v$ is the kinematic viscosity of water $\left(1.00 \times 10^{-06} \mathrm{~m}^{2} \mathrm{~s}^{-1}\right)$.

The characterization of the flow in the annular space of the two cylinders and the hydrodynamic regime in the TCR is also carried out via the dimensionless Taylor number (Ta) (Equation 2). It is characterized by the ratio of the centrifugal forces to the viscous forces (Taylor 1935). Depending on the rotational speed of the inner cylinder, TCR generates different flow regimes. As explained above, the flow inside the TCR must be turbulent since particle aggregation, or biofilm formation, occurs in these hydrodynamic conditions found inside the drippers. According to Coufort (2004), in order to ensure the presence of a turbulent 
regime in the TCR the value of Ta (Equation 2) must be higher than $68.10^{3}$. While the expression of the Taylor number can take many forms, the relation presented by Racina and Kind (2006) was adopted:

$T a=\frac{\Omega \cdot R_{1}^{0.5} e^{1.5}}{v}$

To obtain the desired shear stress for biofilm development, angular velocity $(\Omega)$ must be determined. The shear stress, which is mainly applied to the surface of the inner and outer cylinder, is connected to the tangential flow, itself linked to the rotation of the rotor. This shear stress is generated by the velocity gradient near the surface of the reactor. It is uniform over the internal and external cylinders. Different correlations have been established to estimate the shear stress on the inner cylinder surface. The equations used in the work of Rochex et al. (2008) (Equation 3 and Equation 4), based on the theoretical concept of Wendt (1933) were selected because, in their work, they used an annular reactor configuration with a radius ratio close to the present TCR $\left(\eta=\mathrm{R}_{1} / \mathrm{R}_{2}=0.808\right)$ :

$$
\begin{array}{ll}
\tau=2.13 \frac{(\mathrm{R} 1 /(\mathrm{e}+\mathrm{R} 1))^{3 / 2}}{(\mathrm{e} /(\mathrm{e}+\mathrm{R} 1))^{7 / 4}} \operatorname{Re}^{1.445} \frac{\rho v^{2}}{2 \pi \mathrm{R} 1^{2}} & \text { for } \mathrm{Re}>8.10^{2} \\
\tau=0.113 \frac{(\mathrm{R} 1 /(\mathrm{e}+\mathrm{R} 1))^{3 / 2}}{(\mathrm{e} /(\mathrm{e}+\mathrm{R} 1))^{7 / 4}} \mathrm{Re}^{1.764} \frac{\rho v^{2}}{2 \pi \mathrm{R} 1^{2}} & \text { for } \operatorname{Re}>10^{4}
\end{array}
$$

With $\tau$ : the shear stress expressed in pressure units $(\mathrm{Pa}) ; \rho$ : water density $\left(1000 \mathrm{~kg} \mathrm{~m}^{-3}\right)$

These equations determine the angular velocity of the rotor in order to have shear stress conditions which are those encountered in irrigation pipes and drippers. Every rotational velocity of the cylinder corresponds to a specific shear stress value.

Three shear stress values will be studied, 0.7 $\mathrm{Pa}, 2.2 \mathrm{~Pa}$ and $4.4 \mathrm{~Pa}$ corresponding to $67,128.5$ and 190 RPM respectively. 
The wall shear stress of $0.7 \mathrm{~Pa}$ is encountered in a $16 \mathrm{~mm}$ diameter PE pipe when water velocity is $0.4 \mathrm{~m} \mathrm{~s}^{-1}$. For turbulent flows, wall shear stress is calculated from the Blasius formula (Equation 5) (Chadwick and Morfett 1993).

$\tau=0.0395 * R e^{-0.25} * \rho * V^{2}$

with: $\tau$ : wall shear stress (Pa) ; Re : Reynolds number inside the pipe; $\rho$ : water density (1000 $\left.\mathrm{kg} \cdot \mathrm{m}^{-3}\right)$; V: flow velocity $\left(\mathrm{m} \mathrm{s}^{-1}\right)$.

Velocity of $0.4 \mathrm{~m} \mathrm{~s}^{-1}$ and shear stress of $0.7 \mathrm{~Pa}$ was chosen as a follow-up to the work of Gamri (2014). Gamri (2014) demonstrated that the initiation phase of biofilm development at these conditions occurs only in 10 day contrary to a velocity of $1.2 \mathrm{~m} \mathrm{~s}^{-1}$ where the shear stress is $4.9 \mathrm{~Pa}$ and the initiation phase of biofilm development occurs after 21 days. In the work of Li et al. (2012) using a similar pipe maximum biofilm thickness was reached for a velocity of $0.45 \mathrm{~m} \mathrm{~s}^{-1}$ corresponding to a shear stress of $0.81 \mathrm{~Pa}$.

The two others shear stress values (2.2 and 4.4 Pa) are found inside the dripper canal (Al Muhammad et al. 2016) depending on its geometry. An integrated dripper with non-uniform section (GR type dripper) was chosen because it is used world-wide in micro-irrigation (Al Muhammad et al. 2016). Two inlet flow rate of $1.44 \mathrm{l} \mathrm{h}^{-1}$ and $2.88 \mathrm{l} \mathrm{h}^{-1}$ were used that correspond respectively: to a Reynold number of 400 and 800 , and to shear stresses of 2.2 and 4.4 Pa. More details on the calculation of shear stress inside the dripper can be found in $\mathrm{Al}$ Muhammad et al. (2016).

\section{Experimental set-up and growth conditions}

A 2 liter TCR were used to develop biofilm under different shear stresses. It was fed continuously with tertiary treated wastewater using a peristaltic pump and a water container 
positioned upstream from the TCR (Figure 2). The peristaltic pump delivered a fixed flow rate of $8.28 \times 10^{-2} 1 \mathrm{~h}^{-1}$ to achieve an average residence time of $24 \mathrm{~h}$ for water inside the reactor. 24 hours was chosen to facilitate attachment and development of biofilm over the plates and minimize suspended cell growth (Rochex et al. 2008). A thermostatic bath was used to keep the water at a constant temperature during the experiments $\left(\mathrm{T}=21 \pm 1^{\circ} \mathrm{C}\right)$. Every $53 \mathrm{~h}(3$ times per week) the water container was filled with fresh wastewater to maintain a chemical oxygen demand (COD) inferior to $30 \mathrm{mg} \mathrm{l}^{-1}$ (Table 1). The effluent was collected every two weeks from the sewage treatment plant and was stored in a PVC container at $4{ }^{\circ} \mathrm{C}$ in the refrigerator to help maintain sample integrity (Wagner et al. 2006). During the experiments, a portable multiparameter sensor (WTW multi 3430 set F) was used to measure: temperature, conductivity, dissolved oxygen concentrations and $\mathrm{pH}$ to ensure constant water quality for biofilm development. Chemical oxygen demand (COD) was measured using a WTW kit reagent revealed under a photometer. The reactor specific charge was $0.049 \mathrm{mg}$ COD day ${ }^{-1}$ $\mathrm{cm}^{-2}$. Experiments were run in an open system, and the water surplus was sent as overflow to another tank where the water was then disposed of (figure 2). [Figure 2 near here]

Treated wastewater used in the experiments came from the clarifier outlet of an urban wastewater treatment plant (WWTP) in Mauguio (a town close to Montpellier, in the south of France). It was an activated sludge system where effluents are pretreated with a sieve at 2500 $\mu \mathrm{m}$ before being sent to the sand filter (coarse sand TEN $1.4 \mathrm{~mm}$ ). The water quality of a sample taken in March 2012 is presented in Table 1, it provides a full physicochemical effluent analyses. Other routine analyzes of the effluent quality have been made by the Mauguio station from august 2013 till march 2016 more details are provided in Rizk et al. (2017). [Table 1 near here] 


\section{Sampling}

To study biofilm development under 0.7, 2.2 and 4.4 Pa over time, every experiment, was run continuously over a total period of 8 weeks. Each experiment corresponds to dedicated shear stress value. Periodically: at week $2,3,4,5$ and 6 , some plates were removed to analyze biofilm development. The plates were scraped using a soft plastic band to collect the fouling material. Before a new biofilm development test, each plate were cleaned with a soft paper towel under flowing tap water and then immersed for $10 \mathrm{~min}$ in a slightly acid solution $\left(0.01 \mathrm{M} \mathrm{H}_{2} \mathrm{PO}_{4}{ }^{-}\right)$to remove the remaining fouling material. Before further use, a final rinse with distilled water was carried out. Two repetitions were made for the same plate. At week 8 all the plates were removed and scraped to collect the fouling material in ceramic crucibles for analysis purposes. The results obtained from the scraping activities will represent the second repetition of the experiment.

\section{Characterization of the fouling material}

Fouling material that had accumulated on the plates was transferred into ceramic crucibles, then oven-dried for $24 \mathrm{~h}$ at $105^{\circ} \mathrm{C}$, and weighed to obtain the total solids (TS) contained per unit square $\left(\mathrm{cm}^{2}\right)$ of plates. The volatile solids (VS) content was determined after exposing the organic matter $(\mathrm{OM})$ for 2 hours at $550^{\circ} \mathrm{C}$. The $\mathrm{OM}$ can be equated to biofilm. What was left in the crucibles is the inorganic material (IM). The IM is considered as the chemical precipitation that occurred concurrently with biofilm development. It is highlighted by the use of thermogravimetric analysis (TGA) and X-ray diffraction (XRD). TGA studies were made on a Netzsch STA 449 F1. The system was purged with an inert gas which is argon and heated at a rate of $10^{\circ} \mathrm{C} / \mathrm{min}$, from room temperature to $1000^{\circ} \mathrm{C}$. Both TGA and its derivative (DTG) were simultaneously plotted versus temperature. This system was also coupled with a mass spectrometer (TG-MS) to be able to analyze gases and, in particular, volatile 
decomposition products of thermal analysis. This allows identification of the escape of $\mathrm{CO}_{2}$ in the analysis of calcium carbonate. X-ray powder diffraction patterns were recorded on a PHILIPS X'Pert MPD $\theta-\theta$ diffractometer equipped with the X'Celerator detector with $\mathrm{Cu} k \alpha$ radiation $(\lambda=1.5418 \AA)$ and nickel filter. The $2 \theta$ range was $5-70^{\circ} \mathrm{C}$ with a step size of $0.033^{\circ}$ and a counting time of $3 \mathrm{~s}$ per step. In all cases, samples were finely ground in an agate mortar and deposited onto low-background silicon plates with a drop of ethanol to get a homogeneous and thin layer of powder.

TGA and XRD are able to determine the quality of the precipitate. XRD characterizes the crystallography of the chemical precipitation, and TGA determines the non-crystalized precipitate form and the proportion of each one.

For each shear stress value, the first repetition was used for the identification of TS, VS, XRD and TGA and the second one only for TS, XRD and TGA respectively. For each shear stress, fouling collected from the five strips was mixed together first, to ensure a sufficient quantity for XRD and TGA analysis and second, to give us a general idea of formed precipitate.

\section{Results and discussion:}

\section{Validation of the biofilm development kinetics monitoring protocol}

In order to use the TCR as a tool to develop and to monitor the biofilm over time, biofilm growth must not depend on the position of the plate inside the reactor (figure 1). For repeatability validation, three experiments were carried out using a shear stress value of 2.2 Pa over a period of 2 weeks. After 2 weeks of growth the five plates were removed at the same time to examine any spatial variation of the fouling. The fouling amount was verified by measuring TS $\left(\mathrm{mg} \mathrm{cm}^{-2}\right)$. Table 2 shows the results of TS for the 3 repetitions for each plate. [Table 2 near here] 
Since the collected quantity is very low, any differences between the samples could be linked to measurement error (operator + balance + surface of each plate). A Kruskal-Wallis test was used as a statistical treatment to asses that there were no differences on TS depending on the plate position. Based on this value $(\mathrm{p}=0.26)$, it can be deduced that fouling levels were very consistent over the five plates and it can be affirmed that the hydrodynamic conditions in the TCR are homogeneous enough to identify biofilm development velocity under shear stress conditions.

\section{Evolution of fouling within the TCR over time under different shear stress conditions}

In order to analyze the effect of shear stress on biofilm development, the TCR was operated for a period of eight weeks, under 3 different shear stress conditions commonly found in irrigation pipes $(0.7 \mathrm{~Pa})$ and drippers $(2.2 \mathrm{~Pa}$ and $4.4 \mathrm{~Pa})$. The biofilm was quantified through the measurement of total solids (TS) (figure 3) and volatile solids (VS) masses (figure 4). The results allowed the characterization of biofilm development as a function of shear stress and time (biofilm age in days). Based on previous observations, an initial 14-day development period was applied to allow biofilm initiation. Earlier development was considered insufficient to be measured due to the difficulty in collecting very small quantities of fouling. This phase, which generally takes a minimum of 10 days, corresponds to the initiation phase. [Figure 3 near here]

In figure 3 it can be observed that after the initiation phase (14 days) all the curves follow the same trend for $0.7,2.2$ and 4.4 Pa respectively. The curves can be divided into two phases: the first phase between 14 and 28 days of biofilm age with a constant increase in TS amounts and a second phase between 28 and 42 days (but not necessarily at 28 days especially for $2.2 \mathrm{~Pa}$ ) of biofilm age where stabilization, or a plateau, was observed. In the second phase, the 
quantity collected varied probably due to some detachment. Maximum biofilm development for the three shear stress conditions seems to have been reached at the end of the experiment (day 42). The quantities of TS are higher for a shear stress value equal to $4.4 \mathrm{~Pa}$ over the whole experiment when compared to the other shear stress values. To better explain the development of biofilm as a function of time and shear stress, the amount of organic matter $(\mathrm{OM})$ in the fouling was determined (table 3) (since $\mathrm{OM}$ can be considered to equate to biofilm quantity). [Table 3 near here]

In all of the samples and for the three shear stress values the mean values in percentage of organic material (OM) is less than $50 \%$. Since the sample is mainly composed of IM, the effect of shear stress on biofilm development must be monitored for the organic part of the fouling. The quantity of volatile solids (VS) which corresponds to the quantity of OM is represented in figure 4. [Figure 4 near here]

Figure 4 highlights the effect of shear stress on the organic portion of biofilm development. As previously described, the biofilm initiation phase lasts around 14 days whatever the shear stress. Over 56 days of operation the maximum age of the biofilm was 42 days. From day 20 a difference in the amount of VS emerges s between the three shear stresses. For a shear stress value of $4.4 \mathrm{~Pa}$ the VS obtained is 1.5 to 3 times greater $\left(0.078 \mathrm{mg} \mathrm{cm}^{-2}\right)$ than that obtained with a shear stress value of $2.2\left(0.044 \mathrm{mg} \mathrm{cm}^{-2}\right)$ or $0.7 \mathrm{~Pa}\left(0.02 \mathrm{mg} \mathrm{cm}^{-2}\right)$, respectively.

For $0.7 \mathrm{~Pa}$ the organic proportion of the biofilm remain constant until day 28. For 2.2 $\mathrm{Pa}$ the quantity of OM increases until day 35 and thereafter it seems that detachment and growth are balanced. For 4.4Pa growth continued over the whole experiment. The high shear stress level generated by high velocities reduce the thickness of the diffuse layer which favored greater adhesion of the bacteria (Liu and Tray 2002; Vrouwenvelder et al. 2010). This induces the 
production of exopolymers and specifically polysaccharides in higher quantities than for lower shear stress levels, thus ensuring a more rigid structure with a greater cohesion between the cells (Decho 2000). In figure 4 it is observed that when the shear stress increases, the attachment and the development of the biofilm also increase. Wasche et al. (2002) observed the impact of hydrodynamic conditions on biofilm development inside a tube reactor. The increase in the Reynolds number from 650 to 6000 leads to an increase in biofilm density. In this study, the Reynolds numbers were greater than the study cited above and were equal to 27605 for $4.4 \mathrm{~Pa}, 18621$ for $2.2 \mathrm{~Pa}$ and equal to 9709 for $0.7 \mathrm{~Pa}$ respectively. In order to withstand a high Reynolds number or shear stresses, biofilms develop a denser structure with a more compact and stable biofilm that is more resistant to detachment, which may explain our results confirmed by Kwok et al. (1998), Melo and Vieira (1999) and Picioreanu et al. (2001).

\section{Characterization of the fouling inside the TCR}

As showed in table 3 at the end of the experiment the percentage of OM accumulated for a shear stress value at 4.4 $\mathrm{Pa}(29.5 \%)$ is greater than at 2.2 $\mathrm{Pa}(22.7 \%)$ which, in turn, is greater than at $0.7 \mathrm{~Pa}(16.5 \%)$. This is a very important point since the fouling for the three shear stress values is mainly composed of inorganic material (table 3), and therefore analyzing the chemical composition of the fouling may help understand the links between biological and chemical clogging according to the hydrodynamic conditions when using Mauguio treated wastewater. Two methods were used here for the chemical characterization of the fouling accumulated in the 2 repeatability tests: X-ray diffractometry (XRD) and thermogravimetric analysis (TGA).

$X$-ray diffraction (XRD) analysis of the fouling inside TCR 
X-ray diffraction (XRD) was used to determine the mineralogy and the crystalline phase of the chemical precipitation produced along with the biofilm development using Mauguio wastewater effluent. Figure 5 shows the diffraction pattern of the fouling obtained for a shear stress of 4.4 $\mathrm{Pa}$ in the TCR. Figure 5.a shows the diffraction peaks of the TS, and figure 5.b shows the diffraction peaks of the inorganic matter (IM) obtained after TS calcination. In these two figures three characteristic peaks were highlighted. The most intense peak of calcite $\left(\mathrm{CaCO}_{3}\right)$ is measured at 29.5 in $2 \theta$ position and the second that follows is measured at 23 in $2 \theta$ position (number 1 above peaks). The most intense peak of silicone dioxide $\left(\mathrm{SiO}_{2}\right)$ is measured at 26.5 in $2 \theta$ position and the second that follows is measured at 21 in $2 \theta$ position (number 2 above peaks). The presence of $\mathrm{SiO}_{2}$ (quartz) is due to the presence of small particles of sand and sandstone in the effluent water and which were trapped in the biofilm matrix. The third interesting peak is that of hematite $\left(\mathrm{FeO}_{3}\right)$ (number 3 above peaks) where the most intense one is measured at 36 in $2 \theta$ position. Hematite is a compound found in sedimentary rocks, and some fine particles can also be found in wastewater. In figure 5.b, a fourth interesting peak is observed in the IM sample which is that of calcium oxide $(\mathrm{CaO})$ (number 4 above peaks). The difference between the TS sample and the IM sample is that TS was obtained after desiccation of the sample at $105^{\circ} \mathrm{C}$, and IM was obtained after the TS was placed in the oven at $550^{\circ} \mathrm{C}$ for 2 hours. $\mathrm{CaO}$ was produced inside the oven since no $\mathrm{CaO}$ peaks were detected for the TS sample, (figure 5.a). $\mathrm{CaO}$ presence stems from the decomposition of calcium carbonate (calcite,) which is already present in TS due to calcination (Rizk et al. 2017).

In the IM sample (figure 5.b), some remaining traces of calcite were recorded, which proves that the whole calcium carbonate was not calcinated as the temperature was only raised to $550^{\circ} \mathrm{C}$ to eliminate organic matter. The decomposition of calcium carbonate (calcination) occurred at higher temperatures $\left(500^{\circ} \mathrm{C}-1000^{\circ} \mathrm{C}\right)$, which demonstrates the presence of both 
calcite and calcium oxide in the sample. Regarding the other shear stress values, the results of the XRD were similar to that of 4.4 Pa. The peaks areas of each constituent do not represent the quantity of the elements since the XRD is a qualitative and non-quantitative method. [Figure 5 near here]

According to Rizk et al. (2017), calcite was the most abundant constituent found in chemical elements precipitate in treated wastewater from the Mauguio WWTP destined for irrigation. Calcite was also found (figure 5) inside the fouling obtained in TCR using the same treated wastewater. TCR experiments were carried out at an ambient temperature $\left(\mathrm{T}<25^{\circ} \mathrm{C}\right)$ and for $\mathrm{pH}<8$. In the work of Rizk et al. (2017) no precipitation of calcite was detected in these conditions. This could demonstrate the possible interaction between the biofilm and the $\mathrm{Ca}^{2+}$ in wastewater inducing precipitation. Similarly, Tourney and Ngwenya (2009) found that extracellular polymeric substances (EPS) release dissolved organic carbon (DOC), which complexes $\mathrm{Ca}^{2+}$ ions in solution, thus favoring calcite precipitation, which, in turn, reduces calcium carbonate saturation.

Other elements have also been detected by the XRD such as feldspars and clays, which are essential constituents of rocks and soils present in the effluent. Thermogravimetric analysis (TGA) will be used not only to detect amorphous elements, which is impossible with XRD but also to establish a link between the percentage of OM and calcite precipitation.

\section{Thermogravimetric analysis (TGA) of the fouling inside TCR}

Thermogravimetric analysis (TGA) was used to detect amorphous structure by studying the decomposition of the sample as temperature increases. From the same results, an estimation of the percentage mass of calcium carbonate composing each sample could be made; it is reported in table 4 . From $0^{\circ} \mathrm{C}$ to $550^{\circ} \mathrm{C}$ the mass loss in percentage corresponds to the $\mathrm{OM}$ present in the sample. From $600^{\circ} \mathrm{C}$ to $850^{\circ} \mathrm{C}$, the values correspond to the relative mass of 
calcium carbonate that decomposed under the influence of temperature. The percentage of calcium carbonate in the sample was calculated based on Li et al. (2013). The mass loss of a pure sample of calcium carbonate corresponds to $43.8 \%$ of the total mass. These decomposition values obtained for calcium carbonate at these temperatures is confirmed by DRX analysis. [Table 4 near here]

Note that the samples used for the measurements of organic matter $(\mathrm{OM})$ in TGA could not be the same samples used for the measurement of VS presented in figure 4. The type of degradation that occurs in an oven is called combustion (due to the presence of oxygen), while in the TGA it is the result of pyrolysis (due to the presence of argon). Pyrolysis is the chemical decomposition of organic material at high temperatures in the absence of oxygen or any other reagents.

Comparison between the percentages of organic matter values here and the quantity of VS in figure 4 is impossible, however, in both cases; samples contain more IM than OM. According to table 4 the maximum percentage of $\mathrm{OM}$ was found for a shear stress value of $0.7 \mathrm{~Pa}$ and this represents $48.3 \%$, while according to figure 4 the maximum quantity of VS was found for a shear stress value of $4.4 \mathrm{~Pa}$. Results in Table 4 show the analogous and well correlated evolution of percentage of $\mathrm{OM}$ and percentage of calcium carbonate in the sample $(\mathrm{y}=$ $\left.0.3841 \mathrm{x}-5.5007, \mathrm{R}^{2}=0.925\right)$.

This was also observed by Obst et al. (2009) where an extensive production of EPS were shown to be the main factors involved in the acceleration of carbonate mineralization. Other researchers have been working on the process of biomineralization, especially with respect to calcium carbonate precipitation (Benzerara et al. 2006; Wei et al. 2015). This process is often associated with microbial cell surface structures and metabolic activities while microbial EPS play a very important role in the morphology and mineralogy of calcium carbonate 
precipitation. EPS can trap and bind remarkable quantities of calcium to facilitate precipitation (Arp et al. 1999; Dupraz and Visscher 2005; Braissant et al. 2007). This might be of interest as an approach to improve our understanding of biological and chemical clogging of drippers with TWW.

\section{Conclusion}

In the present work, it was confirmed that the use of treated wastewater applied through micro-irrigation induces dripper clogging, which is due to biofilm development and chemical precipitation. Apart from treated wastewater quality factors, the development of biofilm is mainly favored by hydrodynamic conditions. A number of shear stresses values were selected based on those calculated in irrigation pipes $(0.7 \mathrm{~Pa})$ and in integrated drippers $(2.2$ and 4.4 Pa) which are the most commercially available worldwide in micro-irrigation. In this work, we studied how different shear stress conditions, encountered in irrigation systems, influence biofouling development and evolution based on Taylor-Couette reactor (TCR) experiments. The TCR was used to reproduce different shear stress conditions and to develop biofilm under controlled conditions. The amount of total solids (TS), organic matter (OM) and inorganic matter (IM) for each fouling obtained for different shear stress values were quantified and qualified. X- ray diffraction (XRD) was used to determine the mineralogy and the crystallography of the chemical precipitates produced at the same time as the biofilm development. Thermogravimetric analysis (TGA) was used to detect amorphous structures and a quantitative measure of precipitated calcite. Several important results were obtained:

- The total quantity of solids (TS) accumulated and the quantity of volatile solids (VS) which correspond also to the quantity of organic matter $(\mathrm{OM})$ and biofilm are greater at the highest shear stress (4.4 Pa) value compared to 2.2 $\mathrm{Pa}$ and $0.7 \mathrm{~Pa}$ values. 
- High shear stress favors the supply of substrate in biofilms, and consequently their development leading to a denser and more rigid biofilm that can withstand severe hydrodynamics conditions.

- The characterization of the fouling shows that all samples are mainly composed of inorganic matter (IM). XRD and TGA were used to identify chemical fouling. Calcium carbonate in the form of calcite was detected in all the samples.

- The greater the proportion of OM contained in the sample, the more it can precipitate calcite. This was highlighted using XRD and TGA. This is due to the presence of EPS that can trap and bind remarkable quantities of calcium and facilitate calcite precipitation.

Based on these findings, lower shear stress is recommended when applying municipal tertiary effluent in order to minimize biofilm development. We also recommend that water with low concentrations of calcium and carbonates be used in micro-irrigation to avoid calcium carbonate precipitation. If this is not feasible, measures must be taken like acidification for example, in order to lower the saturation index below the precipitation threshold without overly acidifying the irrigation water, as this would be harmful the soil and plants (Imas and Cohen 2009).

However, there are still some issues that require further study:

- We need a better understanding of biofilm development under hydrodynamic conditions encountered in micro-irrigation, and the effects and interaction between calcium carbonate and biofilm.

- Biofilm must be developed experimentally with and without calcium carbonate to better understand the link between them.

- The use of a confocal laser scanning microscope, and/or Optical Coherence Topography (OCT) would be required to pursue the development of the biofilm 
closely regarding biofilm thickness, density and structure and to be able to detect and to understand chemical precipitation.

\section{ACKNOWLEDGEMENTS}

The authors gratefully acknowledge the financial support of the NGO T.E.R.R.E Liban and the Water4Crops FP7 project, "Integrating bio-TWW with enhanced water use efficiency to support the Green Economy in EU and India", N 311933 and also wish to thank the Institute Charles Gerhardt Montpellier UMR 5253 CNRS - UM-ENSCM for their help with the XRD and TGA tests.

\section{REFERENCES}

Al-Muhammad J. (2016). Flow in millimetric-channel: numerical and experimental study [Thesis]. Ecole Centrale de Marseille.

Al-Muhammad J, Tomas S, Anselmet F. (2016). Modeling a week turbulent flow in a narrow and wavy channel: case of micro-irrigation. Irrigation Science. 34(5):361-377.

Araujo P, Malheiro J, Machado I, Mergulhao F, Melo L, Simoes M. 2016. Influence of flow velocity on the characteristics of Pseudomonas fluorescens biofilms J. Environ. Eng. 142:04016031 
Arp G, Thiel V, Reimer A, Michaelis W, Reitner J. 1999. Biofilm exopolymers control microbialite formation at thermal springs discharging into the alkaline Pyramid Lake, Nevada, USA. Sedimentary Geology. 126:159-176.

Benzerara K, Menguy N, Lopez-Garcia P, Yoon TH, Kazmierczak J, Tyliszczak T. 2006. Nanoscale detection of organic signatures in carbonate microbialites. Proc. Natl. Acad. Sci. U.S.A. 103:9440-9445

Besemer K, Singer G, Limberger R, Chlup AK, Hochedlinger G, Hödl I, Baranyi C, Battin TJ. 2007. Biophysical controls on community succession in stream biofilms. Appl Environ Microbiol. 2007;73:4966-4974.

Bounoua S. 2010. Etude du colmatage des systèmes d'irrigation localisée [Study of the localized irrigation systems clogging] [Thesis]. Aix Marseille University. 109p.

Braissant O, Decho AW, Dupraz C, Glunk C, Przekop KM, Visscher PT. 2007. Exopolymeric substance of sulfate-reducing bacteria: interactions with calcium at alkaline $\mathrm{pH}$ and implication for formation of carbonate minerals. Geobiology. 5:401-411.

Bucks DA, Nakayama FS, Gilbert RG. 1979. Trickle irrigation water quality and preventive maintenance. Agricultural Water Management. 2(2): 149-162.

Chadwick A, Morfett J. 1993. Hydraulics in civil and environmental engineering. Chapman and Hall. 2nd edition.

Characklis WG. 1981. Bioengineering report: Fouling biofilm development: A process analysis. Biotechnology and Bioengineering, 23(9):1923-1960.

Characklis WG, Trulear MG, Bryers JD, Zelver N. 1982. Dynamics of biofilm processes: methods, Water Research, Volume 16, Issue 7, Pages 1207-1216, ISSN 0043-1354. 
Characklis WG. 1990. Laboratory biofilm reactor. In: Characklis WG, Marshall KC. (Eds.), Biofilms. John Wiley and Sons, New York, pp. 55-89

Coufort C. 2004. Analyse expérimentale de la floculation en réacteur de Taylor-Couette : Influence de l'hydrodynamique sur les phénomènes d'agglomération et de rupture [Experimental analysis flocculation in a Taylor-Couette reactor: Influence of hydrodynamics on agglomeration and rupture phenomena ] [Thesis]. INSA Toulouse.

Dazhuang Y, Zhihui B. Rowan M. Likun G. Shumei R. Peiling Y. 2009. Biofilm structure and its influence on clogging in drip irrigation emitters distributing reclaimed wastewater. Journal of Environmental Sciences, v.21, p.834-841.

Decho AW. 2000. Microbial biofilms in intertidal systems: an overview. Cont. Shelf Res.20: $1257-1273$.

Derlon N, Massé A, Escudié R, Bernet N, Paul P. 2008. Stratification in the cohesion of biofilms grown under various environmental conditions, Water Research. 42(8-9):2102-2110.

Dupraz C, Visscher PT. 2005. Microbial lithification in marine stromatolites and hypersaline mats. Trends Microbiol. 13:429-438.

Gamri S, Soric A, Tomas S, Molle B, Roche N. 2014. Biofilm development in microirrigation emitters for wastewater reuse. Irrigation Science. 32(1):77-85.

Gamri S. 2014. Réutilisation des eaux usées traitées en irrigation localisée: impact des conditions d'écoulement et des matériaux sur le développement de biofilm [Reuse of treated wastewater in localized irrigation: impact of flow conditions and materials on biofilm development] [Thesis]. Université d'Aix Marseille. P178

Gomes IB, Simões M, Simões LC. 2014. An overview on the reactors to study drinking water biofilms. Water Res. 62:63-87.10.1016/j.watres.2014.05.039 
Horn H, Reiff H, Morgenroth E. 2003. Simulation of growth and detachment in biofilm systems under defined hydrodynamic conditions. Biotechnology and Bioengineering. 81(5): 607-617.

Imas P, Cohen A. 2009. Improving the $\mathrm{pH}$ of irrigation waters with acidic fertilizers. The Proceedings of the International Plant Nutrition Colloquium XVI. P4.

Krivilyov M, Detandt Y, Abeele DV, Degrez G, Fransaer J. 2006. Direct numerical simulations of Taylor-Couette flow using a hybrid spectral/finite element approach. in: Proc. of the 7th National Conference on Theoretical and Applied Mechanics, Mons, Belgium. 6p.

Kwok W, Picioreanu C, Ong S, Van Loosdrecht M, Ng W, Heijnen J. 1998. Influence of biomass production and detachment forces on biofilm structures in a biofilm airlift suspension reactor. Biotechnology and Bioengineering, 58(4): 400-407.

Landau L and Lifchitz E. 1989. Theoretical physics volume 6: Fluid Mechanics. Institute of physical Problems, U.S.S.R Academy of Sciences. 752p Translated from Russian by Sykes JB and Reid WH.

Li GB, Li YK, Xu TW, Liu YZ, Jin H, Yang PL, Yan DZ, Ren SM, Tian ZF. 2012. Effects of average velocity on the growth and surface topography of biofilms attached on the reclaimed wastewater drip irrigation system laterals. Irrigation Science 30: 103-113.

Li XG, Lv Y, Ma BG, Wang WQ, Jian SW. 2013. Decomposition kinetic characteristics of calcium carbonate containing organic acids by TGA, Arabian Journal of Chemistry. Available online 21 September 2013.

Liu Y, Tay JH. 2002. The essential role of hydrodynamic shear force in the formation of biofilm and granular sludge. Water Research. 36(7):1653-1665. 
Liu H, Huang G. 2009. Laboratory experiment on drip emitter clogging with fresh water and treated sewage effluent. Agricultural Water Management, v.96, p.745-756.

Megersa G, Abdulahi J. 2015. Irrigation system in Israel: A review." International Journal of Water Resources and Environmental Engineering 7.3 (2015): 29-37.

Melo L, Vieira M. 1999. Physical stability and biological activity of biofilms under turbulent flow and low substrate concentration. Bioprocess Engineering. 20(4):363-368.

Niu W, Liu L, Chen X. 2012. Influence of fine particle size and concentration on the clogging of labyrinth emitters. Irrig Sci. 31(4):545-555.

Obst M, Dynes J, Lawrence J, Swerhone G, Benzerara K, Karunakaran C, Kaznatcheev K, Tyliszczak T, Hitchcock AP. 2009. Precipitation of amorphous $\mathrm{CaCO}_{3}$ (aragonite-like) by cyanobacteria: a STXM study of the influence of EPS on the nucleation process. Geochim. Cosmochim. Acta 73:4180-4198.

Picioreanu C, Van Loosdrecht MC, Heijnen JJ. 2001. Two-dimensional model of biofilm detachment caused by internal stress from liquid flow. Biotechnology \& Bioengineering. 72(2):205-218.

Racina A, Kind M. 2006. Specific power input and local micro mixing times in turbulent Taylor-Couette flow. Exp. Fluids 41: 513-522.

Rochex A, Godon JJ, Bernet N, Escudié R. 2008. Role of shear stress on composition, diversity and dynamics of biofilm bacterial communities. Water Research. 42(20):4915-4922.

Rizk N, Ait-Mouheb N, Bourrié G, Molle B, Roche N. 2017. Parameters controlling chemical deposits in micro-irrigation with treated wastewater. Journal of Water Supply: Research and Technology - Aqua. 66. 587-597. 10.2166/aqua.2017.065.

Taylor GI. 1935. Statistical theory of turbulence, Proc. Roy. Soc. London, Ser. A, 421-478. 
Thomen P, Robert J, Monmeyran A, Bitbol AF, Douarche C, Henry N. 2017. Bacterial biofilm under flow: First a physical struggle to stay, then a matter of breathing. PLoS ONE, 12(4), e0175197.

Tourney J, Ngwenya, BT. 2009. Bacterial extracellular polymeric substances (EPS) mediate $\mathrm{CaCO}_{3}$ morphology and polymorphism. Chemical Geology $262: 138-146$.

Vrouwenvelder JS, Buiter J, Riviere M, Van Der Meer WGJ, Loosdrecht, VMC, Kruithof JC. 2010. Impact of flow regime on pressure drop increase and biomass accumulation and morphology in membrane systems. Water Res. 44:689-702.

Wagner RJ, Boulger RW Jr, Oblinger CJ, Smith BA. 2006. Guidelines and standard procedures for continuous water-quality monitors: Station operation, record computation, and data reporting: U.S. Geological Survey Techniques and Methods 1-D3, 51 p

Wasche S, Horn H, Hempel DC. 2002. Influence of growth conditions on biofilm development and mass transfer at the bulk/biofilm interface. Water Research. 36(19):4775.

Wei Q, Shi Y, Dong W, Lu G, Huang S. 2006. Study on hydraulic performance of drip emitters by computational fluid dynamics. Agricultural Water Management. 84(1-2):130-136.

Wei S, Cui H, Jiang Z, Liu H, He H, Fang N. 2015. Biomineralization processes of calcite induced by bacteria isolated from marine sediments. Braz. J. Microbiol. 46:455-464.

Wendt F. 1933. Turbulente Strömungen zwischen zwei rotierenden Zylindern [Turbulent flows between two rotating cylinders]. Ingenieurs-Archiv. 4:577-595. 
Table 1: Physicochemical characteristics of the effluent from the Mauguio WWTP

\begin{tabular}{|c|c|c|c|}
\hline Parameters & values & Parameters & values \\
\hline $\mathrm{T}\left({ }^{\circ} \mathrm{C}\right)$ & 17 & N Kjeldhal (mg Ntot $\left.1^{-1}\right)$ & 2.31 \\
\hline Turbidity & 2.03 & Fluorine $\left(\mathrm{mg} \mathrm{l}^{-1}\right)$ & $<0.50$ \\
\hline $\mathrm{pH}$ & 7.8 & Aluminium $\left(\mu \mathrm{g}^{-1}\right)$ & $<20$ \\
\hline Conductivity $\left(\mu \mathrm{S} \mathrm{cm}^{-1}\right)$ & 1270 & $\mathrm{Br}\left(\mathrm{mg} \mathrm{l}^{-1}\right)$ & 0.18 \\
\hline $\operatorname{TDS}\left(\mathrm{mg} \mathrm{l}^{-1}\right)$ & 1241.7 & $\mathrm{~B}\left(\mathrm{mg} \mathrm{l}^{-1}\right)$ & 0.14 \\
\hline Hardness $\left(\mathrm{mg} \mathrm{l}^{-1}\right)$ & 223 & $\mathrm{Ba}\left(\mathrm{mg} \mathrm{l}^{-1}\right)$ & $<0.05$ \\
\hline Alkalinity $\left(\mathrm{mg} \mathrm{l}^{-1}\right)$ & $<20$ & $\mathrm{Cd}\left(\mathrm{mg} \mathrm{l}^{-1}\right)$ & $<0.005$ \\
\hline $\mathrm{CAT}\left(\mathrm{mg} \mathrm{l}^{-1}\right)$ & 261 & $\mathrm{Cu}\left(\mathrm{mg} \mathrm{l}^{-1}\right)$ & $<0.02$ \\
\hline Ammonium (mg Ntot $1^{-1}$ ) & 0.37 & $\mathrm{Fe}\left(\mathrm{mg} \mathrm{l}^{-1}\right)$ & $<0.05$ \\
\hline Nitrates $\left(\mathrm{mg} \mathrm{l}^{-1}\right)$ & 9.8 & $\operatorname{Mn}\left(\mathrm{mg} \mathrm{l}^{-1}\right)$ & 0.03 \\
\hline Nitrites $\left(\mathrm{mg} \mathrm{l}^{-1}\right)$ & 0.17 & $\operatorname{Li}\left(\mathrm{mg} \mathrm{l}^{-1}\right)$ & $<0.02$ \\
\hline Phosphorus (mg Ptot $1^{-1}$ ) & 0.17 & $\mathrm{~Pb}\left(\mathrm{mg} \mathrm{l}^{-1}\right)$ & $<0.05$ \\
\hline
\end{tabular}




\begin{tabular}{|l|l|l|l|}
\hline $\mathrm{Mg}\left(\mathrm{mg} \mathrm{l}^{-1}\right)$ & 7 & $\mathrm{Si}\left(\mathrm{mg} \mathrm{l}^{-1}\right)$ & 12 \\
\hline $\mathrm{Ca}\left(\mathrm{mg} \mathrm{l}^{-1}\right)$ & 133 & $\mathrm{Sr}\left(\mathrm{mg} \mathrm{l}^{-1}\right)$ & 0.39 \\
\hline $\mathrm{Na}\left(\mathrm{mg} \mathrm{l}^{-1}\right)$ & 119 & $\mathrm{Zn}\left(\mathrm{mg} \mathrm{l}^{-1}\right)$ & 0.03 \\
\hline $\mathrm{Cl}\left(\mathrm{mg} \mathrm{l}^{-1}\right)$ & 171 & $\mathrm{COD}\left(\mathrm{mg} \mathrm{l}^{-1}\right)$ & $<30$ \\
\hline $\mathrm{K}\left(\mathrm{mg} \mathrm{l}^{-1}\right)$ & 18,1 & TOC $\left(\mathrm{mg} \mathrm{l}^{-1}\right)$ & 6,8 \\
\hline Sulfates $\left(\mathrm{mg} \mathrm{l}^{-1}\right)$ & 109 & Total TSS $\left(\mathrm{mg} \mathrm{l}^{-1}\right)$ & 5 \\
\hline
\end{tabular}

Table 2: Total solids values $\left(\mathrm{mg} \mathrm{cm}^{-2}\right)$ for each plate for the three repetitions with their mean values and standard deviation (SD).

\begin{tabular}{|l|l|l|l|l|l|}
\hline $\begin{array}{l}\text { Plate } \\
\text { number }\end{array}$ & Repetition 1 & Repetition 2 & Repetition 3 & Mean values & $\begin{array}{l}\text { Standard } \\
\text { deviation (SD) }\end{array}$ \\
\hline 1 & $5,35 \mathrm{E}-02$ & $6,99 \mathrm{E}-02$ & $5,92 \mathrm{E}-02$ & $6,09 \mathrm{E}-02$ & $8,33 \mathrm{E}-03$ \\
\hline 2 & $7,81 \mathrm{E}-02$ & $8,22 \mathrm{E}-02$ & $7,03 \mathrm{E}-02$ & $7,69 \mathrm{E}-02$ & $6,05 \mathrm{E}-03$ \\
\hline 3 & $7,81 \mathrm{E}-02$ & $6,58 \mathrm{E}-02$ & $7,15 \mathrm{E}-02$ & $7,18 \mathrm{E}-02$ & $6,16 \mathrm{E}-03$ \\
\hline 4 & $9,05 \mathrm{E}-02$ & $6,99 \mathrm{E}-02$ & $6,54 \mathrm{E}-02$ & $7,53 \mathrm{E}-02$ & $1,34 \mathrm{E}-02$ \\
\hline 5 & $9,46 \mathrm{E}-02$ & $6,58 \mathrm{E}-02$ & $7,28 \mathrm{E}-02$ & $7,77 \mathrm{E}-02$ & $1,50 \mathrm{E}-02$ \\
\hline
\end{tabular}

Table 3: Percentage of organic matter (OM) only at the end of the experiment (day 42), the mean values with their standard error of the mean (SEM) with respect to the TS for different shear stresses values.

\begin{tabular}{|l|l|l|l|}
\hline $\begin{array}{l}\text { Shear stress } \\
(\mathbf{P a})\end{array}$ & $\begin{array}{l}\text { End of experiment } \\
(\mathbf{d a y} 42)\end{array}$ & Mean values & $\begin{array}{l}\text { Standard error of the mean } \\
(\text { SEM })\end{array}$ \\
\hline 0.7 & $16.5 \%$ & $17.2 \%$ & 1.26 \\
\hline 2.2 & $22.7 \%$ & $37.6 \%$ & 4.84 \\
\hline 4.4 & $29.5 \%$ & $25.3 \%$ & 2.42 \\
\hline
\end{tabular}


Table 4: Mass loss in percentage between $0^{\circ} \mathrm{C}-550^{\circ} \mathrm{C}, 600^{\circ} \mathrm{C}-850^{\circ} \mathrm{C}$ for different shear stress values and an estimation of the percentage of calcium carbonate in each sample

\begin{tabular}{|l|l|l|l|}
\hline Samples & $\begin{array}{l}\text { Mass loss \% } \\
\left(\mathbf{0}^{\circ} \mathbf{C}-\mathbf{5 5 0}^{\circ} \mathbf{C}\right) \\
\mathbf{O M}\end{array}$ & $\begin{array}{l}\text { Mass loss \% } \\
\left(\mathbf{6 0 0}^{\circ} \mathbf{C}-\mathbf{8 5 0}^{\circ} \mathbf{C}\right) \\
\text { From total mass } \\
\mathbf{I M}\end{array}$ & $\begin{array}{l}\text { Percentage of calcium } \\
\text { carbonate in the sample }\end{array}$ \\
\hline $0.7 \mathrm{~Pa} \mathrm{TS}$ & $48.3 \%$ & $6 \%$ & $13.69 \%$ \\
\hline $2.2 \mathrm{~Pa} \mathrm{TS}$ & $25.2 \%$ & $2.2 \%$ & $5 \%$ \\
\hline $4.4 \mathrm{~Pa} \mathrm{TS}$ & $35.3 \%$ & $2.9 \%$ & $6.6 \%$ \\
\hline
\end{tabular}

